\title{
COMPARISON OF THE FAMILIARITY OF GRADE 4 ROMA AND NON-ROMA SCHOOL CHILDREN WITH SOME BIOLOGICAL TERMS IN ENGLISH AS A FOREIGN LANGUAGE
}

\author{
Authors: \\ Vladimir Legac $(\mathrm{PhD})$ \\ University of Zagreb (Croatia) \\ Darinka Kiš-Novak $(\mathrm{PhD})$ \\ University of Zagreb (Croatia) \\ Goran Lapat $(\mathrm{PhD})$ \\ University of Zagreb (Croatia) \\ E-mail address of first author: \\ vladimir.legac@gmail.com
}

\section{Lectors:}

Magdolna Nemes (PhD)

University of Debrecen

Norbert Tóth

University of Debrecen

Legac, V., Kiš-Novak, D. \& Goran, Lapat (2020). Comparison of the Familiarity of Grade 4 Roma and Non-roma School Children with Some Biological Terms in English as a Foreign Language. Különleges Bánásmód, 6. (1). 47-60. DOI 10.18458/KB.2020.1.47

\begin{abstract}
Most of the Roma settlements in Croatia are spatially segregated from the settlements of the majority population. Specific cultural elements constitute the ethnic border towards the local population, making it difficult and reducing the possibility of their integration into the majority population. One of the results of that segregation is the unfamiliarity of the Roma children with the language of the majority population. This unfamiliarity with the Croatian language is a big obstacle for the integration of the Roma children into Croatian society through school education. Starting from Grade 1 they follow the regular school curriculum. Two of the subjects that are taught from the very beginning of their primary school education are Natural Science and English as a foreign language. In this paper, the authors present the results (statistical analysis and discussion) of their research study. It compares the familiarity of Roma and Non-Roma Grade 4 children (age 10) with some biological terms in English as a foreign language. Based on the results of their research, the authors suggest modifications of the school curriculum for Roma children that would enable their better school achievement and subsequently their easier integration into Croatian socie-
\end{abstract} ty.

Keywords: biological terms, English, Roma and non-roma school children

Discipline: pedagogy 


\section{Absztrakt \\ NEGYEDIK OSZTÁLYOS ROMA ÉS NEM ROMA TANULÓK ÖSSZEHASONLÍTÁSA AN- GOL NYELVÜ TERMÉSZETISMERETTEL KAPCSOLATOS KIFEJEZÉSEK ISMERETE ALAP- JÁN}

Horvátországban a legtöbb roma település szegregáltan helyezkedik el a többségi társadalom életterétôl. Lokális szinten az etnikai határt néhány jellegzetes kulturális tényezó képezi, ami megnehezíti a többségi társadalomba való integrálódás lehetőségét. A szegregáció egyik legfőbb következménye, hogy a roma gyerekek nem sajátítják el megfelelően a többségi társadalom nyelvét, ezáltal az iskolai oktatáson keresztül megvalósítható integráció komoly akadályba ütközik. A tanulók már általános iskola első osztályától tanulnak természetismeretet és angolt mint idegen nyelvet. Ebből kiindulva, jelen tanulmány arra vállalkozik (statisztikai elemzések és diskurzusok felhasználásával), hogy negyedik osztályos roma és nem roma tanulókat hasonlítson össze, abban a vonatkozásban, hogy milyen természetismerettel kapcsolatos kifejezéseket ismernek angol nyelven. A kutatási eredmények alapján a szerzők javaslatokat fogalmaznak meg a roma tanulók oktatásával kapcsolatban, abban bízva, hogy a tantervi változtatások következtében jobb tanulmányi eredményeket tudnak majd produkálni, s ezzel a horvát társadalomba való integrálódásuk is új irányt vesz.

Kulcsszavak: természetismeret, angol nyelv, roma és nem roma tanulók

Diszciplína: pedagogy

\section{Introduction}

The research study presented in this paper is a comparison of the familiarity of Grade 4 Roma and Non-Roma school children with some biological terms in Croatian and in English as a foreign language (EFL).

Croatian Primary School lasts eight years. Children start attending it when they are six or seven years old. It is divided into two parts: the so-called lower (Grades 1-4) and higher grades (5-8). In the former children are taught all the core subjects: Croatian (first language for over $90 \%$ of the population), Mathematics, Natural Science, Music, Arts and Physical-Health Education by a single class teacher. English or some other foreign language (German, Italian or French) is also taught as an obligatory subject from Grade 1 by another teacher who is a qualified teacher for that foreign language. Many primary school children also take Religious Education as an optional subject starting from Grade 1. It can be learnt through the whole duration of Primary School and it is also taught by a teacher who is not a regular class teacher but a qualified teacher for that subject. In the latter (higher grades) children have more subjects and they are all taught by a different qualified teacher. In Grades 1-4 children learn about biological terms in the subject that is called Science and Social Studies (in Croatian: prirodaidruštvo). In English speaking countries it is usually referred to as Science.

Research for this study was interdisciplinary and was carried out in the Medimurje County. The researchers were three scholars and teacher trainers employed at the Faculty of Teacher Education of 
the University of Zagreb: a biologist, a pedagogue and a linguist. They were interested in this topic because of the characteristics of the Roma national group and their educational problems and their problems with integration into the Croatian society.

\section{Roma National Minority in Croatia and their problems of integration into the Croatian society}

According to the results of the 2011 census (Državnizavod za statistiku, 2011) there are 16.975 members of the Roma national group in Croatia, or $0.4 \%$ of the whole population. They are the fifth largest national minority group of 22 that are recognized in the country. Larger minority groups in Croatia are Serbs (186.633 or $4.36 \%$ ), Bosnians (31.478 or $0.73 \%$, Italians (17.807 or $0.42 \%$ ) and Albanians (17513 or $0.41 \%$ ).

The same source reveals that the most of the Roma live in the northern part of the country. 5107 Roma live in the Medimurska County. It is the smallest one in Croatia and Roma constitute 4.49 $\%$ of the whole population of that county and are the largest national minority in that area. Most Roma in that county state Romanian as their first language and not Romani Chip which is a very common first language among Romani population in the rest of the country.

Roma are an ethnic minority group that are least integrated into the modern Croatian society of all ethnic minorities. There are two main reasons for this. The first relates to the extremely high level of prejudice and stereotypes of the majority population. The consequence of this is the high social distance (Hrvatić, 1996), and the problem of social and spatial segregation of the Roma community (Banovac and Boneta, 2006). Another major problem is the lack of competencies of Roma children in their own language. This means that Roma children do not only learn Croatian lexemes, but no- tions and concepts behind these lexemes (Novak Milić, 2007). Many researchers dealing with the issue of Roma in Croatia agree that education is the best way to integrate the Roma community into Croatian society (Hrvatić, 2000; Šućur, 2000; Dragun, 2000). The authors of this paper agree with Štambuk (2000) who points out that "insisting on training and progress on that plan are a longlasting, expensive and difficult way, but truly the only one that will produce results in the future, and is therefore the only rational one in this respect."Progress in learning of Roma students is largely determined by the specificities and character of the Roma community. Roma communities represent an environment that does not favor education sufficiently (Lapat and Šlezak, 2011).

Roma in the Medimurska County where the research for this paper was conducted also live mainly in their small settlements that are spatially segregated from the majority population. One of the results of that segregation is also the unfamiliarity of the Roma children with Croatian as the majority language. The consequences of this unfamiliarity with the language of instruction and of their ethnic and cultural characteristics are that Roma children are currently lagging behind other school children. Their advancement in learning Croatian is usually slow. As a result of the school enrolment they are supposed to become bilingual and reap some advantageous of bilingualism.

\section{TIMSS (Trends in International Mathemat-} ics and Science Study) Reports 2011 \& 2016

In 2011 Croatian students took part in the TIMSS research study (BuljCulej, 2016). According to 2011 Report on the Results for the Reference Levels for Natural Science, Grade 4 students have the basic knowledge of the thematic domains of the Science of Life, Physical and Chemical Sciences and the Earth Science. Students know the basic 
facts about human health, ecosystems and the physical characteristics and behavior of animals. Croatian Grade 4 students were surveyed again in 2016 (Slobodna Dalmacija, 2016). They progressed in every sense and were above the standard. In Natural Science they were $18^{\text {th }}$ in the world and ninth in Europe of the total of 47 countries that took part in the survey. They got 33 points more than the required average. They got 17 points more than their peers in 2011.

Guidelines from this study were also taken into consideration when the authors constructed their achievement tests for the familiarity of students with biological terms in Croatian and in EFL. See 6.3.

\section{Bilingualism}

\section{and foreign language teaching}

Since 1960's it is generally accepted that a child can benefit from growing up with two languages. Peal and Lambert's study (1962) has shown that bilingualism can result in higher verbal and nonverbal intelligence. According to Hamers and Blanc (2000) bilingual children show advanced metalinguistic awareness in their control of language processing. Cognitive effects of bilingualism appear early in the process of bilingualisation and they do not require high level of bilingual proficiency or balanced competence. Bialystok mentions that bilingual children are aware at an earlier stage of the arbitrariness of the linguistic sign and that they can focus their attention more intensely on a particular, more important segment of information so that they can easily exclude redundant information (Bialystok, 2001). This enables the working memory to process more information. Jessner has pointed out that this metalinguistic awareness is a key element that makes it possible for bilingual students to learn easier a new FL than their monolingual counterparts (Jessner, 2006; 2008). However, it should be noted that some authors have warned that improper and inappropriate treatment of children in their growing up with two languages during educational development can sometimes even have negative effects (Cummins, 1979; 1981; 1991; Verhoeven, 1991; 1994). These two authors have warned that wrong educational development can end up in potential semilingualism of children.

Research with bilingual children that are members of other national minorities in Croatia (mainly Italian and Czech) have shown that bilingual children can outperform monolingual (Croatian) schoolchildren in learning English as a foreign language (EFL). Bilingual children achieved better results in EFL in listening skill (Legac, 2007), speaking skill (Legac, 2014a), writing skill (Legac, 2014b). It was also shown that they had better results in affective factors in EFL than monolingual students. They had lower foreign language anxiety in all stages of the foreign language process (Mihaljević Djigunović and Legac, 2008; Legac, 2012), they were less shy (Legac, 2008) and were more motivated to learn EFL (Legac, 2009). However, the research in learning foreign languages (English and German) with Roma national minority in Croatia has shown different results. They had lower grades and had higher foreign language anxiety (Legac, Mikulan and Siročić 2006), and had a lower selfconcept in learning a foreign language (Legac and Filipan-Žignić, 2004).

\section{Aim of the study}

The aim of this study was to explore the familiarity with biological terms in Croatian and in EFL in Roma and Non-Roma Grade 4 Primary School students. The following two hypotheses were tested:

- $\quad$ H1 - Familiarity with biological terms in Croatian will be lower in Roma than in non-Roma students. 
- $\mathrm{H} 2$ - Familiarity with biological terms in EFL will be lower in Roma than in nonRoma students.

Both hypotheses were grounded on the results of the research studies and literature mentioned in the chapters above.

\section{Methodology}

\section{Variables and problems of evaluation and as- sessment}

Five variables were tested in this research study. Three of them were school grades in three subjects that were important for our research study: school grades in Croatian, school grades in EFL andschool grades in Natural Science and two of them were students familiarity with biological terms: familiarity with biological terms in Croatian and familiarity with biological terms in EFL. They were tested on two groups of participants: Roma and Non-Roma Primary School children. In Croatian Primary School students' achievement is measured with grades. For each subject they are given one of the following five grades: excellent (5), very good (4), average (3), sufficient (2) and insufficient (1). Grade insufficient (1) means that a student has failed. There are different attitudes towards evaluation and assessment and there are different perceptions about it as well as. Evaluation is usually defined as the assignment of a certain grade for student achievement according to agreed criteria (Matijević, 2004). Cindrić et al. consider it to be a process in achieving set goals and curriculum principles (Cindrić, Miljković and Strugar, 2010). These approaches to the assessment coincide with the opinions of teachers who feel that students do not learn for themselves, but rather to have a "position" among their peers, to be subordinate to the teacher, school, and later to their college or univer- sity and finally to their workplace (Kačapor, 2003). The basic purpose of assessment is to achieve the best organization and realization of learning (Krulj, Kačapor and Kulić, 2003). Evaluation has multiple functions:

1) diagnostic - student, teacher and parent get feedback on the achieved results in learning;

2) prognostic - a good grade encourages the students to do even better work, and a worse grade indicates to the student (teacher and parent) the need for a change in work effort, learning and teaching; and

3) motivational - assessment in form of grades can serve as a means of extrinsic motivation for students.

Evaluation and assessment in form of grades in primary school can in addition to all the possible positive effects also have many disadvantages that depend on the teacher as a measuring instrument: personal equation, "first impression" effect, logical error, middle error, error of differentiation, error of contrast and tendency to adjust the criteria for assessing the quality of one particular student group (Grgin, 1986).This last tendency of adjusting the criteria is probably present in all schools but it might also play even amore important role in giving grades to Roma minority students. It is possible that in their efforts to encourage positive discrimination of Roma minority, teacher sometimes give better grades to students that they really deserve. This means that a student can get a positive grade for their achievement although for the same achievement another student from a different group would be given a fail. This was a reason big enough for these three researchers to design their own achievement test that would be used for measuring achievement with participants in this study. 


\section{Participants}

A total of 57 Croatian Roma and non-Roma Grade 4 Primary School students from the Medimurje County took part in the study. 31 of them were boys and 26 were girls. They were all about 10 years old at the time of data collection. They attended four different schools in and around the county capital. Their class teachers and their English as a foreign language teachers were all qualified teachers with a similar teaching experience. The participants were assigned to one of the two groups: Roma (26 students) and non-Roma (31 students). The non-Roma group was the controlled group for our research study. Table 1 below illustrates the breakdown of the Roma participants with reference to their gender and the breakdown of the non-Roma group with the same reference is presented in Table 2 below.

Roma students were from Primary School Vladimir NazorPribislavec (21 students) and Primary School Kuršanec (5 students) and Non-Roma students were from Third Primary School Čakovec (17 students), Primary School Vladimir NazorPribislavec (4 students) and Primary School Strahoninec (10 students).

\section{Instrument}

Only one instrument was used in this study: a self-constructed achievement test. In order to test our participants' familiarity with biological terms in Croatian and in EFL the authorsconstructed a test. It consisted of 30 questions. Students were shown pictures. They had to say in Croatian and English what they presented: e.g. river, lake, see, tree, grass, etc. The test also included two items that are not distinguished in Romani Chip. They were "sheep" and "goat". In Romani Chip, which is the mother tongue of the participants in our study, there is only one lexeme that is used to refer to both of these animal species. It is "birka".

In Croatian there are two different lexemes as in English. They are "ovca" and "koza". For each correct answer in Croatian and English students were given one point. The total theoretical score was 30 for each language and the theoretical range was $0-30$ (0 if the child does not know any right answers and 30 if the child gives all the correct answers for the respective language). All the pictures were slides in a PPT presentation.

The biological terms of our achievement test have been drawn from the current curriculum of the Ministry of Science and Education and the guidelines given by the TIMSS (Trends in International Mathematics and Science Study) for the basic knowledge of thematic units for the domains of the Science of Life, Physical and Chemical Sciences and Earth Science.

Table 1: Characteristics of Roma Participants $(N=26)$

\begin{tabular}{|c|c|c|}
\hline \multirow{2}{*}{ Roma Group } & \multicolumn{2}{|c|}{ Number of students } \\
\cline { 2 - 3 } & Male learners & Female learners \\
\cline { 2 - 3 } & 13 & 13 \\
\hline
\end{tabular}

Table 2: Characteristics of non-Roma participants $(N=31)$

\begin{tabular}{|c|c|c|}
\hline \multirow{2}{*}{$\begin{array}{c}\text { Non-Roma } \\
\text { Group }\end{array}$} & \multicolumn{2}{|c|}{ Number of learners } \\
\cline { 2 - 3 } & Male learners & Female learners \\
\cline { 2 - 3 } & 18 & 13 \\
\hline
\end{tabular}




\section{Procedure}

In all four schools the data were collected in January and February 2017. It should be noted thatchildren's parentshad consented that their children could take part in the study. There was no single case where the parents would not have expressed their willingness. The researchers acquainted the students with the aim of the research and asked them to cooperate. They were guaranteed anonymity. Students came one by one to three examiners (the authors of this text) It usually took them about 5 minutes to answer what was shown in the pictures on the slides.

\section{RESULTS AND DISCUSSION}

The data were analyzed using the statistical package SPSS 17.0 for Windows.

\section{Results of the school grades.}

Grades in three school subjects that were important for this research study were analyzed. They were school grades in Croatian (language of instruction in all subjects and the mother tongue of the majority population in the country), English (the main foreign language), Natural Science (the most relevant subject for the familiarity of students with biological terms). For each variable the authors analyzed the results of the measures of central tendency and variability and they calculated $t$-test results.
The first of these three variables that was compared between Roma and non-Roma students was school grade in Croatian. Better results of the NonRoma participants in this variable can be observed from all the values of the scores of central tendency and variability (see Table 3 below):

- mean is higher in thenon-Roma group than in the Roma group (Roma $=3.23$ and S.D. $=0.9$, non-Roma $=4.74$ and S.D. $=0.44$ )

- median splits the two halves of the scores at a higher value in the non-Roma group; in fact it is at the highest possible point in the non-Roma group (Roma $=3$, non-Roma $=5)$

- mode in the non-Roma group is at the highest possible point and in the Roma group it is much lower $($ Roma $=3$, non-Roma $=5)$

- minimum score in the Roma group is the lowest passing grade and in non-Roma group it is the second best grade (Roma $=2$, non-Roma $=4$ )

- maximum score in the non-Roma group is the best possible grade (5) and in the Roma it is only the second possible passing grade which is two levels lower than in the non-Roma group

It is positive that no student in both groups had the negative grade insufficient (1). It can be seen from Table 4 that the differences between Roma and Non-Roma Croatian students are statistically significant $(t=8.179, p<0.01)$ and that they belong to two different populations.

Table 3: Measures of central tendency and variability - school grades in Croatian $(N=57)$

\begin{tabular}{l|c|c}
\multicolumn{1}{c|}{ Variables } & Roma Students & Non-Roma Croatian Students \\
\hline Number & 26 & 31 \\
Mean & 3.23 & 4.74 \\
Standard Deviation & 0.9 & 0.44 \\
Mode & 3 & 5 \\
Median & 3 & 5 \\
Minimum & 2 & 4 \\
Maximum & 3 & 5 \\
Range & 3 & 1
\end{tabular}


KÜLÖNLEGES BÁNÁSMÓD, VI. ÉVF. 2020/1.

Table 4: Differences between means inschool grades in Croatian (t-test results)

\begin{tabular}{|l|c|c|c|c|c|}
\hline Variables & $\mathrm{N}$ & Mean & $\begin{array}{c}\text { Standard Devi- } \\
\text { ation }\end{array}$ & $t$ & $p$ \\
\cline { 1 - 4 } Roma & 26 & 3.23 & 0.9 & \multirow{2}{*}{8.179} & 0.01 \\
\hline Non-Roma Croatian & 31 & 4.74 & 0.44 & \\
\hline
\end{tabular}

Results of the measures of central tendency and variability for the second school subject (EFL) also show better performance of the nonRoma than Roma participants (see Table 5 below). We can deduce that even in the non-Roma group there are some students who struggle with EFL (as the minimum score is 2 in both groups). However, we can be certain from other values that the number of such students is low in the non-Rom group, whereas in the Roma group there are many more students whose knowledge of English is pretty poor
- $\operatorname{mean}($ Roma $=2.81$ and S.D. $=0.85$, non-Roma $=4.61$ and S.D. $=0.46$ )

- $\operatorname{median}($ Roma $=2$, non-Roma $=5)$

- $\operatorname{mode}($ Roma $=3$, non-Roma $=5)$

It is good again that there are no students with negative grades in neither of the tested groups as well as that there are students with the highest grade (excellent 5) in both groups.

The results of the $t$-test presented in Table 6 prove that the difference between the means in this variable is statistically significant $(t=8.985$, $\mathrm{p}<0.01)$.

Table 5: Measures of central tendency and variability - School Grades in EFL $(N=57)$

\begin{tabular}{l|c|c}
\multicolumn{1}{c|}{ Variables } & Roma Students & Non-Roma Croatian Students \\
\hline Number & 26 & 31 \\
Mean & 2.81 & 4.61 \\
Standard Deviation & 0.85 & 0.46 \\
Mode & 3 & 5 \\
Median & 2 & 5 \\
Minimum & 2 & 2 \\
Maximum & 5 & 5 \\
Range & 3 & 3
\end{tabular}

Table 6: Differences between means inschool grades in EFL (t-test results)

\begin{tabular}{|l|c|c|c|c|c|}
\hline Variables & $\mathrm{N}$ & Mean & $\begin{array}{c}\text { Standard Devi- } \\
\text { ation }\end{array}$ & $t$ & $p$ \\
\cline { 1 - 4 } Roma & 26 & 2.81 & 0.85 & \multirow{2}{*}{8.985} & 0.01 \\
\hline Non-Roma Croatian & 31 & 4.61 & 0.67 & \\
\hline
\end{tabular}


Table 7: Measures of central tendency and variability in school grades in Natural Science $(N=57)$

\begin{tabular}{l|c|c}
\multicolumn{1}{c|}{ Variables } & Roma Students & Non-Roma Croatian Students \\
\hline Number & 26 & 31 \\
Mean & 3.35 & 4.81 \\
Standard Deviation & 0.85 & 0.47 \\
Mode & 3 & 5 \\
Median & 3 & 5 \\
Minimum & 2 & 2 \\
Maximum & 5 & 5 \\
Range & 3 & 3
\end{tabular}

Table 8: Differences between means inschool grades in Natural Science (t-test results)

\begin{tabular}{|l|c|c|c|c|c|}
\hline Variables & $\mathrm{N}$ & Mean & $\begin{array}{c}\text { Standard Devi- } \\
\text { ation }\end{array}$ & $t$ & $p$ \\
\cline { 1 - 4 } Roma & 26 & 3.35 & 0.85 & \multirow{2}{*}{8.19} & 0.01 \\
\hline Non-Roma Croatian & 31 & 4.81 & 0.47 & \\
\hline
\end{tabular}

The results of the central tendency and variability in school grades in Natural Science reveal that the situation in this variable is pretty much the same as in EFL (see Table 7 below). In both groups there are students who have problems in mastering the course materials (the minimum value 2 was again found in both groups, and there are students with the highest grades again in both groups, but the non-Roma students have outperformed the Roma group, which can be seen from other values:

- mean $($ Roma $=3.35$ and S.D. $=0.85$, non-Roma $=4.81$ and S.D. $=0.47$ )

- $\operatorname{median}($ Roma $=3$, non-Roma $=5)$

- $\operatorname{mode}($ Roma $=3$, non-Roma $=5)$

Statistical significance of the differences between the means in school grades in Natural Science can be seen from Table 8 where the results of the $\mathrm{t}$-test procedure are presented $(t=8.19, p-0.01)$.
Results of the achievement tests for the familiarity with biological terms in Croatian and in EFL

The results of all the measures of central tendency and variability (see Table 8 below) have shown that non-Roma students have outperformed the Roma students (values of the mean, mode, median and minimum score are lower in the Roma group than in the non-Roma group), but it can be also seen that Roma students are doing pretty well and that they have mastered these biological terms in

Croatian pretty well:

- mean (Roma $=25.42$ and S.D.=4.99, nonRoma $=28.84$ and S.D. $=2.48$ )

- $\operatorname{median}($ Roma $=26.5$, non-Roma $=30)$

- $\operatorname{mode}($ Roma $=29$, non-Roma=30)

- sum of points (Roma $=661$, non-Roma $=894$ 
KÜLÖNLEGES BÁNÁSMÓD, VI. ÉVF. 2020/1.

Table 9: Measures of central tendency and variability - achievement test: familiarity with biological terms in Croatian (N $=57)$

\begin{tabular}{l|c|c}
\multicolumn{1}{c|}{ Variables } & Roma Students & Non-Roma Croatian Students \\
\hline Number & 26 & 31 \\
Mean & 25.42 & 28.84 \\
Standard Deviation & 4.99 & 2.48 \\
Mode & 29 & 30 \\
Median & 26.5 & 30 \\
Minimum & 7 & 17 \\
Maximum & 30 & 30 \\
Range & 23 & 13 \\
Sum & 661 & 894
\end{tabular}

Table 10: Differences between means in the Achievement test: Familiarity with biological terms in Croatian (t-test results)

\begin{tabular}{|l|c|c|c|c|c|}
\hline Variables & $\mathrm{N}$ & Mean & $\begin{array}{c}\text { Standard Devi- } \\
\text { ation }\end{array}$ & $t$ & $p$ \\
\cline { 1 - 4 } Roma & 26 & 25.42 & 4.99 & \multirow{2}{*}{3.36} & 0.01 \\
\hline Non-Roma Croatian & 31 & 28.84 & 2.48 & \\
\hline
\end{tabular}

It can be seen from Table 10 below that the difference between the means of the two studied groups is statistically significant $(\mathrm{t}=3.36, \mathrm{p}<0.01)$, thus the first hypothesis was confirmed:

H1 - Familiarity with biological terms in Croatian is lower in Roma students than in non-Roma students.

The results of all the measures of central tendency and variability (see Table 11 below) have shown that non-Roma students have outperformed the Roma students (values of the mean, mode, median and minimum score are lower in the Roma group than in the non-Roma group), but it can be also seen that Roma students are not doing well in this subject, in fact, that they lagging behind non-Roma students much more than in the previous variable.

To put it differently, they have not mastered these biological terms in EFL at all well:

- $\quad$ mean $($ Roma $=5.19$ and S.D. $=3.76$, nonRoma $=20.13$ and S.D.=6.2)

- $\quad \operatorname{median}($ Roma $=3.5$, non-Roma $=21)$
- $\quad \operatorname{mode}($ Roma $=3$, non-Roma $=624)$

- $\quad$ sum of points (Roma $=1351$, non-Roma $=894$

Results of the $t$-test presented in Table 12 above show that the difference between means of the two tested groups is also statistically significant in this final variable that was tested in this research study $(t=3.76, p<0.01)$, thus the second hypothesis was confirmed: H2 - Familiarity with biological terms in EFL is lower in Roma students than in non-Roma students.

It should be noted that participants in both groups have shown better results for their familiarity with biological terms in Croatian than in EFL. However, that is quite natural. It is a foreign language to both studied groups, but the results of the Roma group should not be that much below the results of the participants in the non-Roma group. If we want the members of the Roma group to do well in the modern society, then they ought to do well in EFL too. 
Table 11: Measures of Central Tendency and Variability - Achievement test: Familiarity with biological terms in EFL $(N=57)$

\begin{tabular}{l|c|c}
\multicolumn{1}{c|}{ Variables } & Roma Students & Non-Roma Croatian Students \\
\hline Number & 26 & 31 \\
Mean & 5.19 & 20.13 \\
Standard Deviation & 3.76 & 6.2 \\
Mode & 3 & 21 \\
Median & 3.5 & 21 \\
Minimum & 0 & 8 \\
Maximum & 17 & 30 \\
Range & 17 & 22 \\
Sum & 135 & 624
\end{tabular}

Table 12: Differences between means in the Achievement test: Familiarity with biological terms in EFL (t-test results)

\begin{tabular}{|l|c|c|c|c|c|}
\hline Variables & $\mathrm{N}$ & Mean & $\begin{array}{c}\text { Standard Devi- } \\
\text { ation }\end{array}$ & $t$ & $p$ \\
\cline { 1 - 4 } Roma & 26 & 5.19 & 3.76 & \multirow{2}{*}{10.74} & 0.01 \\
\hline Non-Roma Croatian & 31 & 20.13 & 6.2 & \\
\hline
\end{tabular}

\section{Conclusion and implications for further studies}

From the review of the literature and the results of the research studies that were done before this current research study it was clear that Croatian society should work on lowering prejudices and stereotypes of the majority population towards Roma minority, that Roma people should be less segregated and that education of that minority group is the only rational way for their progress. In earlier studies it was also seen that Roma minority themselves should change their attitudes towards education and should regard it as the chief contributor for their success in life. Earlier research studies of bilingualism have pointed to possible advantages of bilingual children from other minority groups in their achievement in learning foreign languages over other students. This advantage was not recorded in earlier studies or Roma minority students in learning foreign languages. One of the possible reasons might have been in the fact that Roma children were not truly bilingual.

The results of this research study have shown that Roma school children have lower school grades in all three school subjects that were taken into consideration. They have confirmed the first and the second of our starting hypotheses

H1 - Familiarity with biological terms in Croatian is lower in Roma students than in non-Roma students

$\mathrm{H} 2$ - Familiarity with biological terms in EFL is lower in Roma students than in non-Roma students.

They have shown much better progress in their familiarity with biological terms in Croatian as the language of school instruction than in EFL.

It can be concluded that Roma students do not reap advantages from their potential bilingualism. 
A later start of FL learning of Roma children should be considered (Grade 2 instead of Grade 1). Getting in touch with two new languages in Grade 1 might be a too large burden for Roma children. There might even be a threat of possible seminlingualism that Cummins $(1979 ; 1981 ; 1991)$ and Verhoeven (1991; 1994) have warned about.

According to the authors of this paper, the results of their research study indicate that it might not be enough to integrate Roma minority students into regular education, but that some modifications might be useful. This modification would mean that Roma minority children could start their learning of foreign languages one year later. This later start might help them to become truly bilingual at the end of their Grade 1. This would entail that they could have better school grades and that they would be better familiar with biological terms as well as in other terms in Croatian as their language of instruction, in EFL and last but not least in their mother tongue as well.

The authors of this paper see implications for further research studies. They think that similar research in these variables (school grades in the same three school subjects as in this research study and in a similar achievement test of familiarity with biological terms in other languages of instruction and the familiarity with biological terms in English and other foreign languages) should be replicated in other countries with Roma and Non-Roma children and other languages of school instruction (Hungarian, Romanian, Serbian, etc.) and different ages of the start of FL learning (Grade 2, Grade 3, Grade 4 or Grade 5) so that wrong conclusions are not drawn.

\section{Bibliography}

Banovac, B. iBoneta, Ž. (2006). Etnička distanca i socijalna (dez)integracija lokalnih zajednica. In: Revija za sociologiju. Vol. 37 (1-2). 21-46.
Bialystok, E. (2001). Bilingualism in Development. Language, Literacy, \& Cognition. Cambridge University Press. Cambridge.

Bulj Culej, J. (2016). TIMSS Izvješce o postignutim rezultatima iz prirodoslovlja. Zagreb: Nacionalni centar za društvena istraživanja.https://www.ncvvo.hr/wpcontent/uploads/2016/01/TIMSS-2011.Izvje $\% \mathrm{C} 5 \% \mathrm{~A} 1 \% \mathrm{C} 4 \% 87 \mathrm{e}-\mathrm{o}-$ postignutimrezultatima-iz-prirodoslovlja.pdf [20th October, 2016]

Cindrić, M., Miljković, D. and Strugar, V. (2010). Didaktika $i$ kurikulum. IEP-D2, Zagreb.

Cummins, J. (1979). Linguistic Interdependence and the Educational Development of Bilingual Children. In: Review of Educational Research. 49, 221-51.

Cummins, J. (1979). Linguistic Interdependence and the Educational Development of Bilingual Children. In: Review of Educational Research. 49: 221-51.

Cummins, J. (1981). The Role of Primary Language Development in Promoting Educational Success for Language Minority Students. In:Schooling and Language Minority Students. Linguistic Interdependence and the Educational Development of Bilingual Children. A Theoretical Framework (Jim Cummins). Department of Education, Evaluation, Dissemination and Assessment Center, Los Anageles. 3-49.

Cummins, J. (1981). The Role of Primary Language Development in Promoting Educational Success for Language Minority Students In: Schooling and Language Minority Students. A Theoretical Framework. (J. Cummins), Department of Education, Evaluation, Dissemination and Assessment Center, Los Angeles. 3-49.

Cummins, J. (1991). Interdependence of First- and Second-Language Proficiency in Bilingual Children. In: E. Bialystok (Ed.) Language Processing in Bilingual Children. Cambridge: Cambridge University Press. 70-89. 
Cummins, J. (1991). Interdependence of First- and Second-Language Proficiency in Bilingual Children. In: E. Bialystok (Ed.) Language Processing in Bilingual Children. Cambridge: Cambridge University Press. 70-89.

Dragun, M. (2000). Podrijetlo, mitologija i vjerovanja Roma. In: Društvena istrǎ̃ivanja. 46-47, 317-333.

Državni zavod za statistiku Republike Hrvatske: Popis stanovništva 2011. http://www.dzs.hr/Hrv/censuses/census2011 /results/htm/H01 _01_04/h01_01_04_RH.html[19th June, 2016.]

Grgin, T. (1986). Školska dokimologija. Školska knjiga, Zagreb.

Hamers, J.F. and Blanc, M. (2000). Bilinguality and Bilingualism. Cambridge University Press, Cambridge.

Hrvatić, N. (1996). Romi u interkulturalnom okružju. In: Drusttvena istraživanja. 25-26, 913 933.

Hrvatić, N. (2000). Odgoj i izobrazba Roma u Hrvatskoj. In: Drustuena istra ̌rivanja. 46-47, 267290.

Jessner, U. (2008). A DST Model of Multilingualism and the Role of Metalinguistic Awareness. In: Modern Language Journal. 92(2), 270-283.

Jessner, U. (2008). Linguistic Awareness in Multinlinguals. Edinburgh: Edinburgh. University Press.

Kačapor, S. (2003). Sadř̌ajiizoposteistorijepedagogije. Grafosinternacional.

Krulj, R., Kačapor, S. and Kulić, R. (2003). Pedagogi$j a$. Svet knjige, Beograd.

Lapat, G. and Šlezak, H. (2011). Percepcija učenika Roma o važnosti obrazovanja. In: Metodički obzori. 6(1-11), 81-93.

Legac, V. (2007). Comparison of Listening Anxiety and Listening Comprehension between Monolingual and Bilingual Learners of English as a Foreign Language in Croatia. In: B. Stein (Ed.)
Wege zu anderen Sprachen und Kulturen. Verlag Dr. Kovač, Hamburg. 159-178.

Legac, V. (2008). Shyness and Achievement in Listening Comprehension of EFL in Croatian Monolingual and Bilingual Students. In: Steinerné Molnar, Judit \& Tóth Sándor., Attila (Eds) Kutatások 2007. Eötvös József Föiskola. Baja. 465-475.

Legac, V. (2010). Intensity of Motivation in Monolingal and Bilingual Students in Learning English. The Relationshilp between Intensity of Motivation and Achievement in Listening Comprehension in English as a Foreign Langauge. In: Tóth Sándor, Attila (Ed.) Kutatások 2009. Eötvös József Föiskola, Baja. 120-128

Legac, V. (2012). Foreign Language Anxiety in Different Stages of the FL Learning Process and Achievement in Speaking Skill of Monollingual and Bilingual EFL Learners. In: Crossing Boundaries in Culture and Communication. 3(1), 29-36.

Legac, V. (2014a). Communication Apprehension and Achievement in Speaking Skill in Monolingual and Bilingual Learners of English as a Foreign Language. In I. De la Cruz Cabanillas \& C. T. Martinez (Eds.) Linguistic Insights: Studies on Languages. Universidad de Alcala Servicio de publicaciones, Alcala de Heneras. 287-300.

Legac, V. (2014b). Foreign Language Anxiety and Achievement in Writing Skill of Monolingual and Bilingual EFL Learners. In Žebrowska, M. Jaworska \& D. Steinhoff (Eds.) Materialität und Medialität der spracblichen Kommunikation Materiality and Mediality of Linguistic Communication. Peter Lang, Frankfurt am Main - Bern - Bruxelles New York - Oxford - Warszawa - Wien. 225234.

Legac, V. and Filipan-Žignić, B. (2004). Pojam o sebi u učenju stranoga jezika u monolingvalnih i bilingvalnih učenika. In: Učitelj. 4, 185-201.

Legac, V., Mikulan, K. and Siročić, D. (2006). Strah od jezika i uspjeh u učenju stranih jezika u monolingvalne i bilingvalne djece u Međimurju. 
In: I. Vodopija (ed.) Dijete i jezik danas. Dijete $i$ višejezičnost. Faculty of Teacher Education of the University of Josip Jurja Strossmayera in Osijek. Osijek. 151-168

Matijević, M. (2004). Ocjenjivanje u osnovnoj školi. Zagreb: Tipex.

Mihaljević Djigunović, J. and Legac, V. (2008). Foreign Language Anxiety and Listening Comprehension of Monolingual and Bilingual EFL Learners.In: Studia Romanica Et Anglica Zagrabiensia. 53, 327-347.

Novak Milić, J. (2007). Hrvatski i romski u prvim godinama školovanja. In: Drugi jezik hrvatski (ed. Cvikić, L.). Zagreb: Profil.

Peal, E. and lambert, W. (2000). Relation of Bilingualism to Intelligence". In: Psychological Monographs. 1962. 76, 1-23.

Slobodna Dalmacija

http://www.slobodnadalmacija.hr/novosti/hrvatsk a/clanak/id/457017/cetvrtasi-su-nam-prieuropskom-vrhua-onda-slijedi-strmoglavi-pad-ine-moze-drugacije-kad-su-nam-nastavnicizadnja-rupa-na-svirali [8th December, 2016.]
Štambuk, M. (2000). Romi u društvenom prostoru Hrvatske.In: Drusttvena istraživanja. 46-47, 197210.

Šućur, Z. (2000). Romi kao marginalna skupina. In: Drustuena istra ̌̌vivanja. 46-47, 211-227.

Verhoeven, L. (1991). Predicting Minority Children's Bilingual Proficiency. Child, Family, and Institutional Factors, In: Language Learning. 41, 205-233.

Verhoeven, L. (1991). Predicting Minority Children's Bilingual Proficiency. In Child, Family, and Institutional Factors, In:Language Learning. 41: 205-233.

Verhoeven, L. (1994). Transfer in Bilingual Development. In The Linguistic Interdependence Hypothesis Revisited, In: Language Learning. 44: 381-415.

Verhoeven, L. (1994). Transfer in Bilingual Development. The Linguistic Interdependence Hypothesis Revisited. In: Language Learning. 44, 381-415. 